\title{
VIOLENCE IN TIMES OF CHANGE: THE LATE INTERMEDIATE PERIOD IN SAN PEDRO DE ATACAMA
}

\author{
VIOLENCIA EN TIEMPOS DE CAMBIO: EL PERÍODO INTERMEDIO \\ TARDÍO EN SAN PEDRO DE ATACAMA
}

\author{
Christina Torres-Rouff*, María A. Costa-Junqueira**, and Agustín Llagostera**
}

\begin{abstract}
The Late Intermediate Period in the Andes (A.D. 1000-1476) witnessed a decline in the prosperity associated with the Middle Horizon and the state of Tiwanaku (A.D. 750-1000). These disruptions are manifested in the construction of fortified sites, migration, and in a paucity of material culture. We investigate whether these changes affected the levels of interpersonal violence in the oases of San Pedro de Atacama, northern Chile. Nearly 150 crania from the Late Intermediate cemetery of Yaye, one of the poorest in the area, were examined for evidence of trauma. They demonstrated a very high frequency of cranial fractures, $29.2 \%$ of the population (42/144), distributed throughout the bones of the skull. These results were compared to contemporary sites, which show similar patterns. Moreover, crania from the Tiwanaku and Inka periods were also analyzed and compared to this data. The populations from these two periods show less evidence of cranial trauma than those from Yaye. In the Tiwanaku Period, 11.9\% of the population is affected (11/92), but in the subsequent Inka Period we see a notable decrease in trauma $(4.0 \%$ or 11/275). These temporal differences in trauma may be associated with the larger cultural changes in the area. The results of this study indicate the possibility that the high rate of trauma seen at Yaye is related to the stress of the Late Intermediate.
\end{abstract}

Key words: bioarchaeology, cranial trauma, San Pedro de Atacama.

Durante el período Intermedio Tardío en los Andes (1.000-1.476 d.C.) se advierte una caída de la prosperidad asociada con el Horizonte Medio y con el estado de Tiwanaku (750-1.000 d.C.). Estas disrupciones se manifiestan en la construcción de sitios fortificados y empobrecimiento material. Hemos investigado si estos cambios incidieron en los niveles de violencia interpersonal en los oasis de San Pedro de Atacama, norte de Chile. Se presentan los resultados del análisis de evidencias de traumas en alrededor de 150 cráneos del cementerio Intermedio Tardío de Yaye, uno de los sitios funerarios más pauperizados del área. El $29,2 \%$ de la población (42/144), presenta señales de golpes en el cráneo. Estos resultados fueron comparados con los de otros sitios de la época (Coyo 3 y Quitor 6 Tardío), los que muestran patrones similares. Se analizaron, además, cráneos del período Tiwanaku (Solcor 3) y del período Inka (Catarpe). Estas poblaciones demuestran menos traumas que los de Yaye, lo que puede representar importantes cambios culturales en el área. Los resultados indican que es posible que la alta tasa de traumas visto en los cráneos de Yaye y otros del Intermedio Tardío se relacione con situaciones de estrés social ocurrido en esa época.

Palabras claves: bioantropología, traumas en el cráneo, San Pedro de Atacama.

The San Pedro de Atacama oases are located in the Atacama Desert of northern Chile (Figure 1). The area has a long history of settlement in prehistoric times. This research will concentrate on temporal changes in the evidence of violence in human skeletal remains from the prehispanic occupation of the Atacama, most specifically from Late Intermediate Period settlements (A.D. 10001476). The Andean chronology, defined by Kroeber (1944) and Rowe (1960), is structured around Horizons interrupted by Intermediate Periods. The Horizons are times when distant areas are understood to be under the influence of pan-Andean systems and, generally, they are characterized as moments of stability. In contrast, the Intermediate Periods are very diverse and are characterized as times of independent regional developments (Moseley 1992). The Middle Horizon (A.D. 7501000) was defined by the large states of Tiwanaku and Wari and generally is considered a time of prosperity and unity. The Late Intermediate begins with the fall of these states and lasts for almost 500 years. During the subsequent Late Horizon (A.D. 1476-1532) the Inka empire expands.

The Late Intermediate Period was an epoch of fragmentation and of the formation of independent

\footnotetext{
* Department of Anthropology, The Colorado College, 14 E. Cache La Poudre Street, Colorado Springs, Colorado, 80903, USA. ctorresrouff@coloradocollege.edu

** Instituto de Investigaciones Arqueológicas y Museo, Universidad Católica del Norte, San Pedro de Atacama, II Región, CHILE.
} 


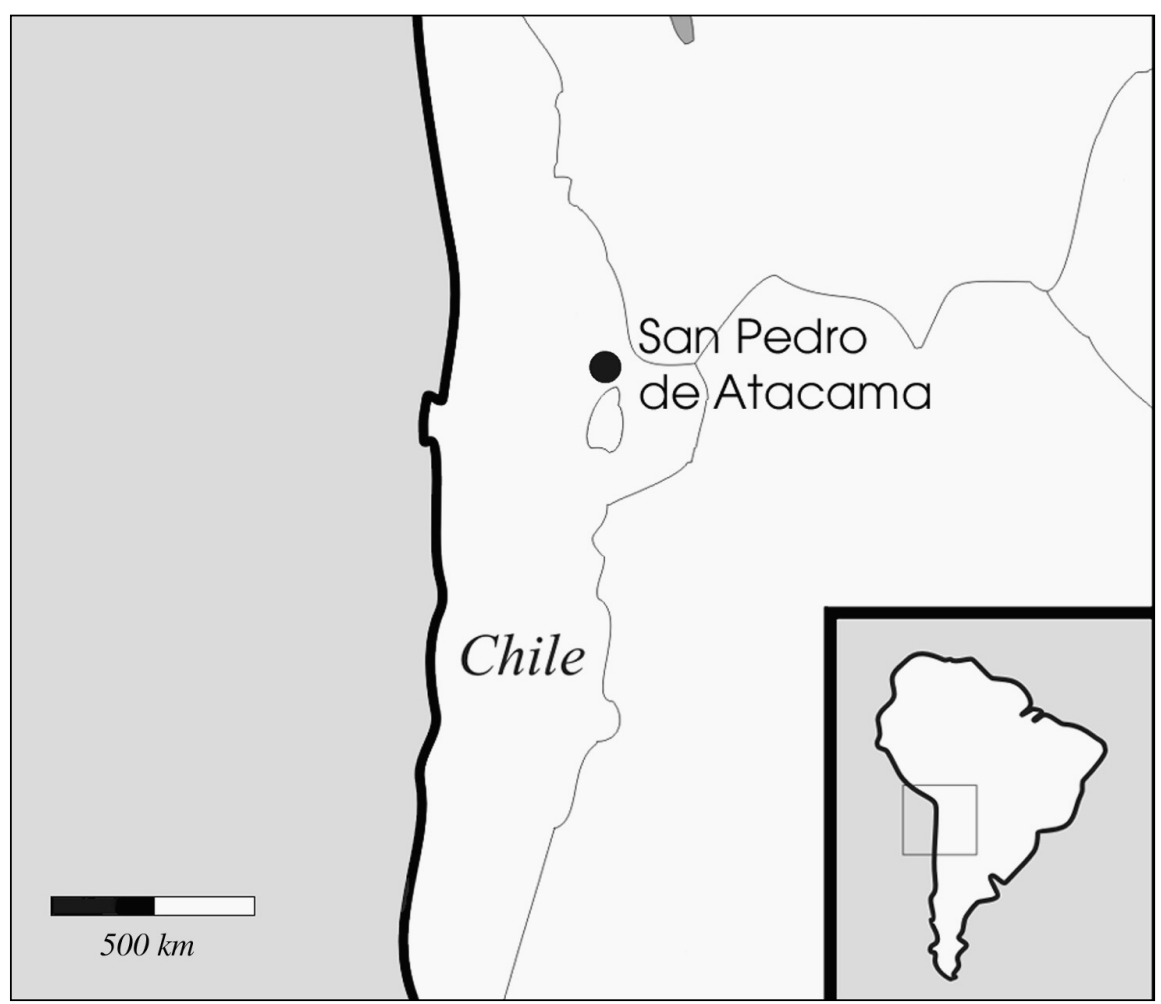

Figure 1. Location of the San Pedro de Atacama oases. Ubicación de los oasis de San Pedro de Atacama.

political bodies throughout the Andes (Moseley 1992). The disruptions of this time are evident in north Chile in the construction of fortified settlements and defensive structures (Mostny 1949). This analysis of human remains from the Late Intermediate Period in the Atacama will help to determine if the social changes of this time affected local populations. Specifically, whether the incidence of traumatic injuries increased in relation to the increase in public demonstrations of defense and fortifications during the Late Intermediate Period.

Crania from three periods in the oases were examined to determine if there were temporal changes in the patterns of violence related to the social changes of the Late Intermediate. If it was a time of social and environmental chaos, we would expect to see this reflected in the rate of injuries. In contrast, if the stress of the Late Intermediate was mediated through mechanisms of local control, we would not expect elevated levels of trauma among these populations. Based on the archaeological evidence from the Late Intermediate, we hypothesize that rates of violence would have increased from those seen in the Middle Horizon. Concomitantly, it is expected that this rate would decrease as a consequence of the expansion of the Inka Empire.

\section{Materials and Methods}

The materials examined in this study were excavated from archaeological cemeteries in San Pedro de Atacama and they are curated at the Museo Arqueológico R. P. Le Paige (Universidad Católica del Norte de Chile; Table 1). A total of 577 skulls were subject to macroscopic analysis for this project. The great majority are the remains of adults, a fact that is not surprising given that the remains of children are often not conserved as well as those of adults (Walker et al. 1988). Only mostly complete skulls were examined; if the skull was largely incomplete it was excluded from analysis. Crania from the four cemeteries of Yaye $(n=144)$, typical cemeteries for the Late Intermediate in the Atacama, are the focus of this study. These cemeteries are located on the western edge of the oases and were 
Table 1 . The study sample.

La muestra de estudio.

\begin{tabular}{lcr}
\hline Period & Site & $\mathrm{n}$ \\
\hline Middle Horizon (A.D. 750-1000) & Solcor 3 & 92 \\
Late Intermediate Period (A.D. 1000-1476) & Coyo 3 & 45 \\
& Yaye & 144 \\
& Quitor 6 & 21 \\
Late Horizon (A.D. 1476-1532) & Catarpe & 275 \\
\hline
\end{tabular}

excavated in 1961 (Le Paige 1961). The data obtained from this examination of remains from Yaye were compared with data from two contemporary cemeteries, Quitor 6 Tardío and Coyo 3.

Quitor 6 is located at the north of the oases, bordering the San Pedro River, and is one of the largest and richest cemeteries of the Middle Horizon in San Pedro de Atacama. Le Paige excavated the Middle Horizon portion in the 1960s. In 1983, in the north sector of Quitor 6, Llagostera and Costa excavated a number of tombs dating to the Late Intermediate: Quitor 6 Tardío (Costa 1988). In this research we analyzed 21 wellpreserved crania from Quitor 6 Tardío. Coyo 3, excavated by Llagostera and Costa between 1989 and 1990, is located southwest of the main cluster of oases and dates to the end of the Middle Horizon and the initial Late Intermediate (Costa and Llagostera 1994). Good skeletal preservation at Coyo 3 resulted in 45 adult crania that were analyzed in this research. Comparisons among these samples will help determine if the patterns of violence observed at Yaye are specific to those cemeteries or if they form part of a general tendency during the Late Intermediate.

Two cemeteries from the Horizon periods that bracket the Late Intermediate were also examined. The cemetery of Solcor 3 is from the Middle Horizon (Bravo and Llagostera 1986); 92 of these individuals were examined in this research. The Catarpe cemeteries were occupied before and during the Inka occupation of this area (Le Paige 1978). The sample from Catarpe consists of 275 skulls. The analysis of these skeletal remains will allow temporal comparisons in order to determine if state influence (in the form of the Tiwanaku and the Inka) affected levels of violence in San Pedro de Atacama.

Determination of sex and age was based on pelvic morphology, cranial sutures, and on the sexually dimorphic characteristics of the skull (Buikstra and Ubelaker 1994). For subadults age was calculated based on dental eruption (Buikstra and Ubelaker 1994). Perimortem traumas were not considered in the analysis due to the uncertainty associated with their identification; this research instead focuses on evidence of healed trauma (Figures 2 and 3; Merbs 1989). Healed traumatic

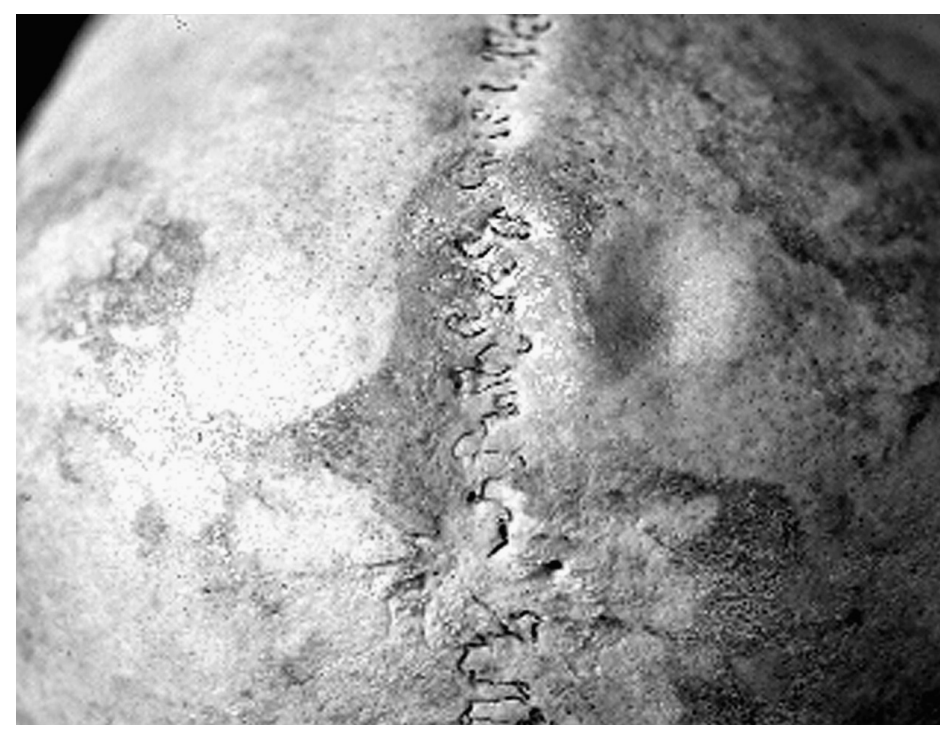

Figure 2. Cranium with healed fracture of the right parietal (Yaye 1501). Cráneo con fractura cicatrizada en el parietal derecho (Yaye 1501). 


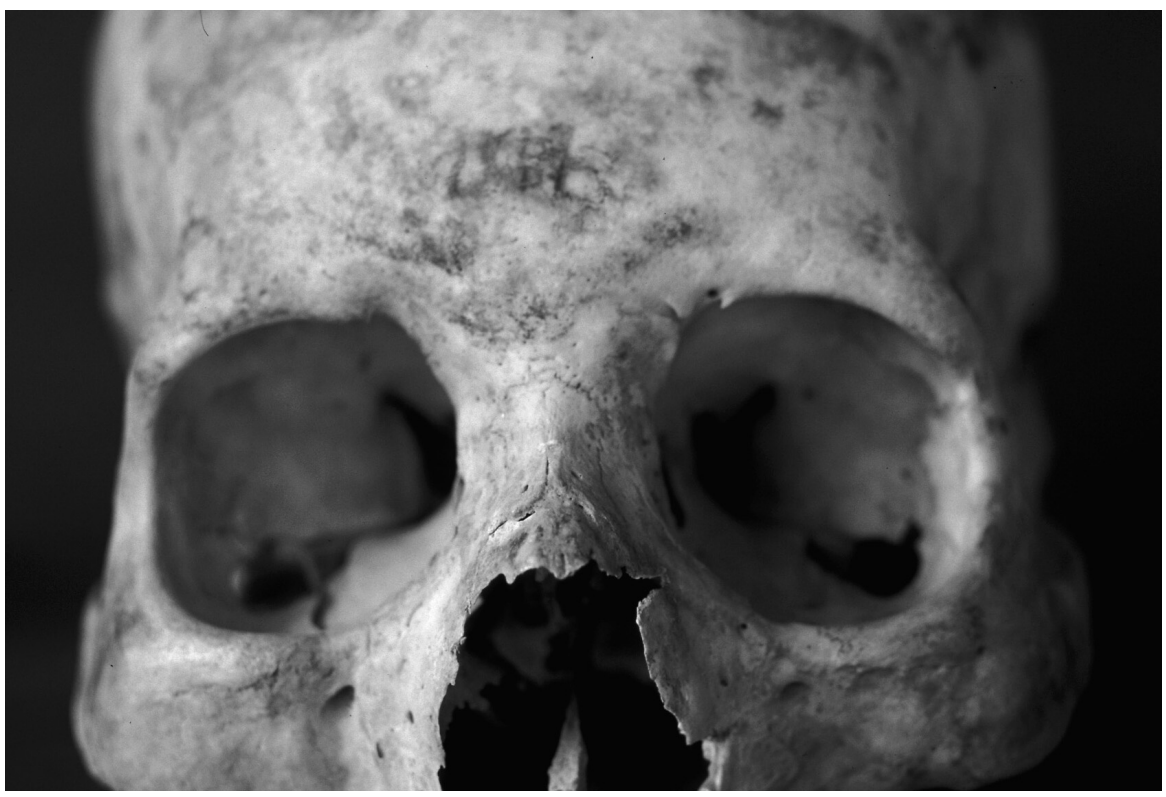

Figure 3. Cranium with healed fractures of the nasal bones (Yaye 1533).

Cráneo con fractura cicatrizada en los huesos nasales (Yaye 1533).

injuries on the crania are evidenced through depressions on the cranial vault, fractures of the facial bones, and injuries resulting from recognized weapons, such as maces or projectile points. These types of wounds are considered the most representative of interpersonal violence, while traumas to the post-cranial skeleton, excluding specific cases such as "parry" fractures, are generally considered to result from accidents or from everyday activities conducted in an inhospitable environment (Alvrus 1999; Judd 2002; Walker 1989). The diameter of each injury was measured, as was the distance to specific craniometric points. State of healing was analyzed and data were also collected on individuals with multiple traumatic injuries.

\section{Results}

\section{The Late Intermediate Period}

The crania analyzed from Yaye included 54 males, 77 females and 13 subadults. Of these 144 skulls, 42 (29.2\%) show evidence of healed trauma. These represent 21 males, 20 females and one subadult (Table 2). There are no significant differences in trauma between the sexes, although wounds are more frequent in males $(38.9 \% \mathrm{v}$. $26.0 \%$ ). The majority of the traumas in Yaye are found on the nasal bones $(n=17)$ and left parietal $(n=13)$. Four individuals from these cemeteries suffered from multiple injuries. Two females had depressed fractures of both parietal bones, and another had healed trauma of the right nasal bone and the left parietal. Finally, a male had fractures of the nasal bones and of the left frontal.

Analysis of other Late Intermediate Period collections from San Pedro de Atacama revealed very similar results to those from Yaye (Table 2). Of the 21 individuals from Quitor 6, five skulls (23.8\%) showed evidence of healed fractures, while in Coyo 3 , more than one third of the cemetery population was affected $(16 / 45 ; 35.6 \%)$. At these two sites trauma occurs in males and females in almost equal frequencies (Coyo 3: females $n=7$, males $n=9$; Quitor 6: females $n=3$, males $n=2$ ). There is no statistically significant difference. Nevertheless, only one individual from Quitor 6 showed evidence of multiple trauma; a female with fractures of the nasal bones and the left parietal. In contrast, at Coyo 3 there are six individuals with multiple traumas. Among the males $(n=3)$, one has fractures of the frontal and right parietal; another of the maxilla and left parietal, and the third, on both parietals. One female suffered fractures of the nasal bones and the 
Table 2. Frequency of healed cranial fractures in the sample from San Pedro de Atacama.

Frecuencias de fracturas de cráneos cicatrizadas en la muestra de San Pedro de Atacama.

\begin{tabular}{|c|c|c|}
\hline & \multicolumn{2}{|c|}{ Presence of trauma } \\
\hline & $\mathrm{n}$ & $\%$ \\
\hline \multicolumn{3}{|l|}{ Solcor 3} \\
\hline Males & $4 / 43$ & 9.3 \\
\hline Females & $7 / 49$ & 14.3 \\
\hline Indeterminate & $0 / 0$ & 0.0 \\
\hline Total & $11 / 92$ & 11.9 \\
\hline \multicolumn{3}{|l|}{ Coyo 3} \\
\hline Males & $9 / 24$ & 37.5 \\
\hline Females & $7 / 21$ & 33.3 \\
\hline Indeterminate & $0 / 0$ & 0.0 \\
\hline Total & $16 / 45$ & 35.6 \\
\hline \multicolumn{3}{|l|}{ Yaye } \\
\hline Males & $20 / 77$ & 26.0 \\
\hline Females & $21 / 54$ & 38.9 \\
\hline Indeterminate & $1 / 13$ & 7.7 \\
\hline Total & $42 / 144$ & 29.2 \\
\hline \multicolumn{3}{|l|}{ Quitor 6} \\
\hline Males & $2 / 6$ & 33.3 \\
\hline Females & $3 / 11$ & 45.5 \\
\hline Indeterminate & $0 / 4$ & 0.0 \\
\hline Total & $5 / 21$ & 23.8 \\
\hline \multicolumn{3}{|l|}{ Catarpe } \\
\hline Males & $8 / 160$ & 5.0 \\
\hline Females & $2 / 77$ & 2.6 \\
\hline Indeterminate & $1 / 37$ & 2.7 \\
\hline Total & $11 / 275$ & 4.0 \\
\hline
\end{tabular}

right parietal, while another has injuries of the nasal bones and the frontal. The third female suffered four cranial fractures: nasal bones, frontal and both parietals. As a group, these cemeteries present an image of the Late Intermediate in San Pedro de Atacama where violence was common.

\section{Temporal changes}

The distribution of trauma at a site from the earlier Middle Horizon was also considered in this study. Solcor 3 was occupied during a period of prosperity and strong influence from the Altiplano state of Tiwanaku. Ninety-two crania were studied. The rate of traumatic injuries was notably lower in this collection than in the cemeteries of the Late Intermediate, with only 11 individuals (11.9\%) showing healed cranial trauma (Table 2). This is significantly different from the frequency of trauma seen at Yaye $\left(c^{2}=9.548 ; p\right.$ 0.002). The traumatic injuries at Solcor 3 are distributed among four males and seven females; there were no significant differences between the sexes. Three of these individuals, all males, had multiple traumatic injuries. One had fractures of the left temporal and left parietal; a pattern that may be related to a single traumatic event. The others each suffered from three distinct injuries: one had three on the frontal, while the other had two on the left parietal and one on the right parietal. In all the cases, the fractures of the vault they were depressed and ovoid.

The Catarpe cemeteries yielded 275 crania. These show the lowest rate of fractures seen in this investigation. Only the $4.0 \%$ of the population $(n=11)$ showed evidence of healed trauma. These included two females, eight males and one sex indeterminate adult. Again, the differences among the sexes were not significant. It is interesting to note that the traumas are more frequent in females at Solcor 3 and Yaye, but in Catarpe, they display the half of wounds seen in the males. The majority of the injuries at Catarpe are located on the nasal bones $(n=4)$, followed by the frontal $(n=3)$ and the parietals $(n=3)$. The difference in rates of violence between Catarpe and Yaye is statistically significant $\left(\mathrm{c}^{2}=56.670 ; \mathrm{p} 0.0001\right)$. Additionally, there are no individuals with multiple injuries. These results indicate considerable variability in the rates of trauma during these three periods in San Pedro de Atacama, which likely reflect changing social conditions.

\section{Discussion}

This analysis shows a clear change in behavior patterns during the Late Intermediate Period. The rate of cranial fractures at Yaye is very high and indicates levels of considerable stress. Our hypothesis that the social and environmental disruptions of the Late Intermediate had a substantial effect on the local population is also supported by the data from Quitor 6 Tardío and Coyo 3. This is particularly evident when these results are compared with the periods surrounding the Late Intermediate. The differences in levels of violence during these three periods serve to evoke the concept behind the Andean chronology, where Horizons are periods of calm and unity. 


\section{Evidence from archaeology}

Archaeological studies of the Late Intermediate in the Atacama suggest conditions of stress that are expressed in burials with poor grave goods, or even none at all. In contrast, during the Middle Horizon, Atacameños were living through a period of prosperity and they had an abundance of interactions and exchanges with foreign groups. The contents of Middle Horizon tombs reflect these conditions. At Solcor 3, individuals show a lower frequency of cranial fractures than in any of the Late Intermediate Period cemeteries. They are found buried with bows and arrow or axes, tools and substantial assemblies of very refined ceramics and textiles. The tombs from this time also commonly include objects from northwest Argentina or the Tiwanaku state (Bravo and Llagostera 1986). Additionally, Neves and Costa (1998) have documented an increase in stature in this period, indicating general economic improvement during Tiwanaku in San Pedro de Atacama.

The transition towards poverty in the Late Intermediate resonates with the fall of Tiwanaku. Exchange with Tiwanaku was constant during the Middle Horizon, and provided important elements for everyday life and ritual in the Atacama (Torres and Conklin 1995). Paleoecological evidence shows that a severe drought gripped the Andes at the beginning of the Late Intermediate (Binford et al. 1997; Ortloff and Kolata 1993). This likely resulted in a decrease in agricultural production, as well as in the availability of pasturelands for grazing camelids. These environmental and cultural changes may have been causative factors for the intensification of violence in the social environment.

During the Late Intermediate, the gourd replaces ceramics as the primary grave good. The majority of burials include only one or two of these objects besides the textiles that wrap the individual. There are no complex mortuary assemblages at Yaye. The portion of the Quitor 6 cemetery that corresponds to the Middle Horizon demonstrated great wealth; the sector corresponding to the Late Intermediate, in contrast, displays funeral objects that not only diminish in quantity, but also in quality of manufacture. This seems to concord with our findings indicating increased stress and violence during this period. The Late Horizon sees a resurgence of prosperity in the Atacama together with the establishment of an Inka presence in the area. Additionally, the droughts of the Late Intermediate have come to an end. The cemetery of Catarpe displays a great variety of objects in graves, including some of Inka affiliation and others of local manufacture (Lynch 1977:145). Paralleling the local prosperity, there is a drastic reduction in skeletal evidence of violence.

\section{Skeletal evidence of violence}

The high frequency of fractures and the distribution of traumatic injuries in individuals of both sexes indicate that conflict was part of life in the Atacama during the Late Intermediate. There is also a substantial increase in individuals with evidence of multiple traumas during this time. Although it is impossible to determine if the wounds are the result of a single episode of violence or of a series of encounters, they support the idea that violence was nearly commonplace. In contrast, comparing the frequencies of postcranial trauma -more often the results of accidents than violencein the Middle Horizon with those of the Late Intermediate, Neves et al. (1999) do not find significant differences. This indicates that the changes seen in the rate of cranial fractures suggest changes in the patterning and frequency of violence in these populations.

If the wounds documented by this study resulted from warlike clashes with neighboring populations, it is probable that they would occur predominantly in the skeletal remains of males. Nevertheless, the fact that females also display significant evidence of violence complicates the matter. It is interesting to note that females suffer from injuries at a similar level to the males (Table 3 ). Analysis of the bones affected indicates that females were subject to the same form of violence that males encountered in this population. Therefore, this does not suggest domestic violence whose presence was intensified by social conditions. Nevertheless, it is very possible that the character of the wars in the pre-Colombian Andes was very different from the modern, western idea, in which bands of males gather and face each other to fight. It has been noted in studies of ancient Nubia that, as a consequence of violence during military incursions and raids, females were also affected by traumas (Alvrus 1999:427). These facts reflect high levels of aggression in the populations under study that likely resulted from environmental 
Table 3. Location of healed cranial fractures.

Localización de las fracturas craneales cicatrizadas.

\begin{tabular}{|c|c|c|c|c|c|c|}
\hline \multirow[t]{2}{*}{ Affected bone } & \multicolumn{2}{|c|}{ Male } & \multicolumn{2}{|c|}{$\begin{array}{c}\text { Sex } \\
\text { Female }\end{array}$} & \multicolumn{2}{|c|}{ Indeterminate } \\
\hline & $\mathrm{n}$ & $\%$ & $\mathrm{n}$ & $\%$ & $\mathrm{n}$ & $\%$ \\
\hline Face & $17 / 310$ & 5.48 & $14 / 213$ & 6.57 & $1 / 54$ & 1.85 \\
\hline Frontal & $13 / 310$ & 4.19 & $9 / 213$ & 4.23 & $1 / 54$ & 1.85 \\
\hline L Parietal & $18 / 310$ & 5.81 & $16 / 213$ & 7.51 & $0 / 54$ & 0.00 \\
\hline R Parietal & $10 / 310$ & 3.23 & $13 / 213$ & 6.10 & $0 / 54$ & 0.00 \\
\hline L Temporal & $2 / 310$ & 0.65 & $0 / 213$ & 0.00 & $0 / 54$ & 0.00 \\
\hline R Temporal & $0 / 310$ & 0.00 & $3 / 213$ & 1.41 & $0 / 54$ & 0.00 \\
\hline Occipital & $1 / 310$ & 0.32 & $0 / 213$ & 0.00 & $0 / 54$ & 0.00 \\
\hline
\end{tabular}

* highest percentage bolded

and social changes. Something similar could have occurred among the Atacameño population. Additionally, it is probable that females participated in the defense of the group. The probability that the oases were subject to frequent attacks is suggested by the construction of fortifications during the Late Intermediate (Mostny 1949).

Although the observed patterns of trauma may be the result of wars and incursions, the possibility of some type of regularized hostilities also exists. Accounts from modern Peru discuss a ritual battle called the tinkuy where the objective is to injure without causing death (Orlove 1994:133). Something similar to this form of conflict resolution exists throughout the Andes and may also have existed in prehistory. It is possible that some of the non-lethal wounds examined in this study could be the result of this type of engagement.

The Chinchorro culture of the north coast of Chile also manifests very high rates of non-lethal trauma. Standen and Arriaza argue that the depressed, consistently elliptic traumas they document are the product of wounds from small stones (Standen and Arriaza 2000:246). They speculate that the Chinchorro may have participated in mock battles as part of their funerary rites (Standen and Arriaza 2000:246). Nevertheless, is more likely than the wounds seen in the population from San Pedro de Atacama are the result of violence among individuals or groups, probably over land and resources. In his study of the Chumash of southern California, Walker (1989) finds that $19.9 \%$ of the crania show evidence of healed fractures. He suggests that this is indicative of conflicts over natural resources in a marginal environment. Similarly, the patterns seen in San Pedro de Atacama during the Late Intermediate can be interpreted as the result of conflicts over limited resources, since there are substantial changes in the environment at this time. This pattern has been seen in other studies of prehistoric violence (Keeley 1997; Lambert 1997; Milner 2000). Environmental stress likely produced great social tensions that, in this population, may have resulted in acts of violence.

In contrast to the pattern seen in the Late Intermediate, the 275 individuals from Catarpe show a completely different distribution of cranial trauma from Yaye and contemporary cemeteries. This may be the result of two complementary themes. First, the Middle Horizon, like the Inka period, was a time of prosperity and foreign influence. This local prosperity and relation with a foreign power may have been a considerable force responsible for the lower frequency of violence in this period. Additionally, the drop in rates at Catarpe could also result from the imposition of some form of peace when the empire expanded.

Although the Inka occupied this area for only a brief time, they built roads, way-stations (tambos), shrines and dwellings throughout the region. Catarpe was an administrative center that was placed in a strategic location that may have served to control the flow of materials through the Atacama (Aldunate and Cornejo 2001:28). It is interesting to think that an imperial presence could have served to repress 
interpersonal violence. This is a pattern supported by other studies of imperial conquest situations. For example, on the south coast of Peru, Kellner notes a decrease in the frequency of cranial fractures from $13.3 \%$ to $6.2 \%$ when the Wari Empire conquered the Nasca valleys (Kellner 2002). The presence of a foreign power in the Atacama, albeit short-lived, concomitant with an improvement in environmental conditions during the Late Horizon, likely promoted a more orderly environment, resulting in the patterns of trauma seen at Catarpe.

\section{Conclusion}

The Late Intermediate Period appears to be a time of great agitation in San Pedro de Atacama. The rates of violent injuries at Yaye are significantly higher than the periods that surround it and suggest that environmental and social changes played an important role in this increased violence. The consistency of the Yaye results with those from other cemeteries from the same period supports the idea that new pressures were affecting this population. It is very probable that the loss of prosperity and prestige after the Middle Horizon was a factor that contributed to these patterns. This may have been exacerbated by the stress caused by regional droughts. It is very probable that the high rates of fractures revealed by this analysis resulted from difficult living conditions. These conditions may have served to amplify hostilities and previously existing conflicts. By the end of the Late Intermediate we see a radical decrease in the frequency of violence in San Pedro de Atacama. These patterns support the idea that the environmental and social turmoil of the Late Intermediate had a profound effect on the lives of Atacameños.

\section{References Cited}

Aldunate, C. and L. Cornejo

2001 Tras la Huella del Inka en Chile. Museo Chileno de Arte Precolombino, Santiago.

Alvrus, A.

1999 Fracture patterns among the Nubians of Semna South, Sudanese Nubia. International Journal of Osteoarchaeology 9:417-429.

Binford, M.W., A.L. Kolata, M. Brenner, J.W. Janusek, M.T. Seddon, M. Abbott and J.H. Curtis

1997 Climate variation and the rise and fall of an Andean civilization. Quaternary Research 47:235-248.

Bravo, L. and A. Llagostera

1986 Solcor 3: un aporte al conocimiento de la cultura San Pedro, período 500 al 900 a.C. Chungara 16-17:323-332.

Buikstra, J.E. and D.H. Ubelaker

1994 Standards for data collection from human skeletal remains. Arkansas Archeological Survey research series; no. 44. Arkansas Archeological Survey, Fayetteville, Ark.

Costa, M.A.

1988 Reconstitución física y cultural de la población tardía del cementerio de Quitor 6 (San Pedro de Atacama). Estudios Atacameños 9:99-126.

Costa, M.A. and A. Llagostera

1994 Coyo 3: Momentos finales del Período Medio en San Pedro de Atacama. Estudios Atacameños 11:73-107.

Judd, M.

2002 Ancient injury recidivism: An example from the Kerma Period of ancient Nubia. International Journal of Osteoarchaeology 12:89-106.

Keeley, L.H.

1997 Frontier warfare in the Early Neolithic. In Troubled Times: Violence and Warfare in the Past, edited by D. Martin and D. Frayer, pp. 303-320. Gordon and Breach Publishers, The Netherlands.
Kellner, C.M.

2002 Coping with stress: Bioarchaeological analyses of Nasca health during the Early Intermediate Period and Early Middle Horizon. Ph.D. Dissertation, University of California, Santa Barbara.

Lambert, P.M.

1997 Patterns of violence in prehistoric hunter-gatherer societies of coastal southern California. In Troubled Times: Violence and Warfare in the Past, edited by D. Martin and D. Frayer, pp. 77-110. Gordon and Breach Publishers, The Netherlands.

Le Paige, G.

1961 Fieldnotes - Yaye. Archives of the Museo Arqueológico, R. P. Le Paige, San Pedro de Atacama, Chile.

1978 Vestigios arqueológicos Incaicos en las cumbres de la zona Atacameña. Estudios Atacameños 6:36-52.

Lynch, T.

1977 Tambo incaico Catarpe Este (Informe de Avance). Estudios Atacameños 5:142-147.

Merbs, C.

1989 Trauma. In Reconstruction of Life from the Skeleton, edited by M. Y. Isçan, pp. 161-190. Liss, New York.

Milner, G.R.

2000 Troubled times: Violence and warfare in the past (book review). American Journal of Physical Anthropology 112:285-286

Moseley, M.E.

1992 The Incas and their Ancestors: the Archaeology of Peru. Thames and Hudson, New York, N.Y.

Mostny, G.

1949 Ciudades atacameñas. Boletín del Museo Nacional de Historia Natural 24:125-211.

Neves, W.A., A.M. Barros and M.A. Costa

1999 Incidence and distribution of postcranial fractures in the prehistoric population of San Pedro de Atacama, 
northern Chile. American Journal of Physical Anthropology 109:253-258.

Neves, W.A. and M.A. Costa

1998 Adult stature and standard of living in the prehistoric Atacama Desert. Current Anthropology 39:278-281.

Orlove, B.

1994 Sticks and stones: Ritual battles and play in the southern peruvian Andes. In Unruly Order: Violence, Power, and Cultural Identity in the High Provinces of Southern Peru, edited by D. Poole, pp. 133-164. Westview Press, Boulder.

Ortloff, C.R. and A.L. Kolata

1993 Climate and collapse-agro-ecological perspectives on the decline of the Tiwanaku State. Journal of Archaeological Science 20:195-221.

Rowe, J.H.

1960 Cultural unity and diversification in peruvian archaeology. In Men and Cultures: Selected Papers of the Fifth International Congress of Anthropological and
Ethnographical Sciences, edited by A. F. C. Wallace, pp. 627-631. University of Pennsylvania Press, Philadelphia. Standen, V.G. and B.T. Arriaza 2000 Trauma in the preceramic coastal populations of northern Chile: Violence or occupational hazards? American Journal of Physical Anthropology 112:239-249.

Torres, C.M. and W.J. Conklin

1995 Exploring the San Pedro de Atacama/Tiwanaku relationship. In Andean Art: Visual Expression and its Relation to Andean Beliefs and Values, edited by P. Dransart, pp. 78-108. Avebury, Hampshire, England.

Walker, P.L.

1989 Cranial injuries as evidence of violence in prehistoric southern California. American Journal of Physical Anthropology 80:313-323.

Walker, P.L., J.R. Johnson and P. Lambert

1988 Age and sex biases in the preservation of human skeletal remains. American Journal of Physical Anthropology 76:183-188. 